\title{
MOOC: a revolution in teaching? A European view
}

\author{
Yves Epelboin $^{1}$ \\ 1University P.M. Curie-Sorbonne Universités, case 1205, 4 place Jussieu, 75252 Paris Cedex 05, \\ France, yves.epelboin@upmc.fr
}

Keywords

Teaching, MOOC, e-learning.

\section{INTRODUCTION}

Since the end of the 90's and the emergence of widely disseminated technologies, Information Technology has been claimed as a strong means to revolutionize the old way of teaching and learning. American universities have focused on new technologies and their use for education since their appearance in the late 90s. With the explosion of the Web technologies, the dream of a full distance education has started to be a reality. The intention of the universities was twofold: to attract new customers far from their traditional recruitment pools and to compete not only with other universities, but also with private companies, such as Phoenix U., which organized classical distance learning with great success. The creation of WGU, a pure online university (WGU 1995) is the best example of this intention. Later, the MIT created the Open Courseware initiative (OCW 2002) which exposes an increasing number of teaching documents to the world. In 2006, the Khan academy (Khan 2006), not especially intended towards Higher Education, invited everyone to add their own short video (less than 10 minutes in most cases) to explain any point of interest. The contributors are all volunteers. Neither their qualifications nor their legitimacy are controlled.

More recently, a new concept, MOOC (Massive Open Online Courses) presented a more ambitious goal. Its aim was to provide a comprehensive education to any public, at world scale, and to deliver an attestation (certification) of completion of study to those who had followed successfully the full course. However one must define what the word "successfully" means. The concept of distance learning is quite old. It has been evolving with the technology and the economic conditions. Are the MOOC a breakthrought in education or a new avatar of an old concept? An excellent review about this issue has been made by Hill (2012).

MOOC promoters distinguish two kinds of MOOC (Tracey 2013): XMOOC which is the extension and adaptation of the classical way of knowledge transmission, adapted to a massive number of apprentices and the connectivist MOOC,C-MOOC, which expects a more active learner. The student is supposed to discuss, to debate and to share his/her knowledge with his fellow learners. He is also encouraged to discover teaching materials in the immensity of the web.

Before further discussing the $M O O C$, it is necessary to explain what kind of pedagogy is characteristic of the socio-economic context of the American universities, to understand to which problem this new concept is supposed to answer.

\section{THE SOCIO-ECONOMIC CONTEXT OF AMERICAN UNIVERSITIES}

The economic model of the American universities is that of a private non-profit enterprise (Desnos \& Epelboin (2002). State universities are no exception. Their mode of income is based largely on student enrollment: students pay for the education they receive, thus the fees depend on the tuition. This is not the case in many European countries where fees are based on a semestrial or yearly period. The cost varies depending on enrollment, hence the concept of a full-time student (FTE) that keeps coming up, when discussing the cost of technological solutions with U.S. suppliers. Thus the price of any teaching unit includes the price of all relevant services, including technology. A university may not hesitate to increase it in order to provide new or improved services. They eventually feed other activities through this money. A community college or a state university will not ask for the same fees as a prestigious private university, not only because its regulations do not allow it, but also because its field of activities is narrower, thus its financial needs. 
Another reason for the push of technology is that competition is a key word in the search for clients, i.e. students, technology can be a good argument not only considering education but also communication opportunities. This is the case at Drexel U., for example, which claims to be always at the front of new technologies.

The American university is in crisis. Registration fees have skyrocketed in the recent years and reached intolerable levels (Fischer 2011). The average level of student debt, when leaving the university, is at a worrying level (Mc Carthy \& Abrams 2012). Universities are aware of this and are looking for parades. Community colleges, state universities have seen their number of students increase after the 2008 crisis. Some economists predict the bursting of a financial bubble in this area.

Technologies are already being used by publishers to respond to this crisis. Contrary to most European universities, American courses are based on books that students are supposed to acquire. Publishers have massively moved to electronic publishing, with the idea of lowering the prices, which rise at an intolerable pace ( $\$ 1,000$ per year per student on average).

$M O O C$ is another way to meet the crisis as OCW was, partially, to meet the cost of publication.

One must also mention, in the American culture, the sincere desire to help those in need (donations, volunteering, alumni donations, corporate support, etc) which is the origin of many generous initiatives to spread knowledge.

\section{THE MOOC CONCEPT}

MOOC is a new concept, where learners study alone, helping each other. They assemble by affinity, language, community, etc. to exchange, share and solve all the difficulties they encounter in their learning. Within this concept the number of participants can be very large. It even reaches 140,000 or more for some courses! At this scale it is no longer possible to envisage a direct interaction with teachers because it would require an incredibly large staff and would increase the cost tremendously. Automatic tests allow participants to check their understanding and assess what they have learned. Teachers are very little involved, giving only general directions through the social tools that are implemented to allow exchanges between learners. People who complete the course are awarded a certificate. The failure rate is very high, above $80 \%$ reaching $90 \%$; the promoters of $M O O C$ reply that, due to the high number of participants, the number of certified students remains honorable.

$\mathrm{x}-\mathrm{MOOC}$ follow the classical way of delivering documents, building tests to verify the progression of the students. Exchanges among students are strongly encouraged through forums, chat rooms and other exchange media. Teachers intervene only vaguely to drive the on-going discussions.

$\mathrm{X}-\mathrm{MOOC}$ are more based on connectivity: everybody brings his/her own knowledge and references. Social tools are of primary importance giving the ability to reach everyone in the entire world regardless of geographical location.

Both approaches to pedagogy, adapted to distance education with very limited interaction with teachers, given the mass of students, require a new student behavior, more proactive, called "Flipped Learning". It reflects the fact that students help each other, support each other, join together (remotely) in a way that best suits them (community, language, affinity, etc.), hence the importance of social networking tools. These concepts are grouped under the name of "crowdsourcing". Promoters of the concept claim that students build networks of relations of interest, not only for their study, but also for their professional life.

People who success in completing the course receive a certification which is not a credential.

The cost of preparing a MOOC is important. A MOOC is not just online documents, already available via the Web:

1. Documents, once used for OCW, must be fully redesigned for this new model. All authors insist on this point. This is not, by far, a simple reuse of existing documents. 
2. The need for automatic or semi-automatic assessment calls for appropriate tools and human resources to design the assessments (teachers associated with specialists of the underlying technologies).

3. Social networking tools must be designed to facilitate interaction between learners.

Conventional LMS are not well adapted to this new concept: they are designed for fine tracking of students and contain a number of tools not necessary in this environment. That is why new tools are being designed.

The most well-known consortia are:

- EdX, http://www.edx.org edX, consortium with Harvard, Berkeley, U. of Texas

- Coursera, http://www.coursera.org, which includes 33 universities around Stanford and claims to be followed by nearly two millions students! In Europe, U. of London, EPFL, U. of Edinburgh, joined the consortium.

- Canvas, http://www.canvas.net, Canvas to which belong Brown U., U of Central Florida and other.

- Udacity, http://www.udacity.com/, which is a company founded by former Stanford University staff members.

- Udemy, http://www.udemy.com, is a commercial consortium with a lot of applied courses, not especially relevant for Higher Education, for a low price between $50 \$$ and $200 \$$.

- FutureLearn, http://www. futurelearn.com/, built around the Open University in the UK. It is the first European consortium and will assemble together a number of UK universities. It is in its very beginning.

One may consult the documentation provided by Educause (2012).

\section{MOOC BUSINESS MODEL}

The discourse about education and pedagogy sometimes seems amazing. It addresses ideas that already exist for many years, in the US as well as in Europe, about the use of technology in education. See, for instance, what has been done at UPMC (Innovatice 2012). This seems, to an outside observer, a little strange because, up to now, the importance of technology has been justified, in particular in the United States, as a push to change the pedagogy. The new concept, here, is the need to process large masses of students, requiring automatic control and monitoring with minimal human intervention. In other words, "flipped learning" appears as a revolution in pedagogy, not because it is more efficient, but because it is needed to handle large numbers of students.

All this means that the decision to go to MOOC requires to mobilize significant financial and human resources. Classical teaching platforms are not suitable: they are not intended for such masses and are designed to enhance interaction with real teachers. One needs to invent new tools, better adapted to mass education, more akin to CMS (Contents Management Systems) as LMS (Learning Management Systems).

American universities, with their considerable resources, have understood that creating a MOOC, requires much more than they can afford. They have assembled in consortia where each university brings some courses. The consortiums are comprehensive enterprises with their employees, officers and funding. edX, which includes Harvard, Berkeley and University of Texas began with $60 \mathrm{MS}$. Its proponents recognize that the business model is not yet defined, each consortium being today supported by the industry. About the purpose of MOOC themselves, nothing is clear. Questioned on this point, the answers from the promoters vary: for some, it is a generous action towards the most disadvantaged, to raise their level of knowledge to be promoted in their company through the acquisition of knowledge not necessarily directly related to their work. Others, such as Drexel U., U. of Central Florida or $\mathrm{U}$. of Colorado, believe that a purely online teaching is a means to filter the entries to the university directly in the second year, at a reasonable price for the students. This would lower the price of the studies compared to an entry in a conventional first year. In this model the $\mathrm{MOOC}$ is no longer free and becomes part of the financial strategy of the universities. Harvard sees it as a means of communication to attract good students and even offer scholarships to those 
who are most successful. A number of American universities are thinking about including MOOCs as a part of a degree program: "Universities bring in students who wouldn't have come to them otherwise, and have a chance to observe the academic preparedness of students before they start a degree program" (Lewin 2013).

MOOCs start to be not so open: in January Coursera announced the introduction of electronically certified certifications "signature track". This shows that certification may become some kind of credential.

\section{MOOC IN EUROPE}

The motivation to establish a MOOC in Europe cannot be the same as in the United States, because the socio-economic context, the cost of education, the role of the state to define the university strategy are completely different. Some experiments already show (iTyPa 2012) that there is public interest for MOOC, certainly not as an alternative to conventional Higher Education (MC Ghee 2012) but to meet the needs which are not covered today: long life education, a gentle manner to learn new things, all opportunities where human beings want to acquire knowledge.

The university is transforming its way of teaching, slowly adapting to new generations of students but is it reaching all the population who want to acquire some skills and knowledge? Some members of the public will never come on our campuses, real or virtual. MOOC is not a way to replace face to face teaching but an alternative to reach a new fraction of population. One of our missions is to transfer knowledge to the general public and $M O O C$ could be one of the means to reach this target.

Another question arises about the use of certification delivered through MOOC. How will the employers judge capacities acquired through this means? How will it compare to degrees earned through examinations in front of teachers? What kind of competency can be acquired through this new means of learning? Some American universities have already decided to integrate courses acquired through MOOCs in their curriculum (Lewin 2013). Will private employers follow? If yes, the University is in great danger. Economists consider Education as the third business of the $21^{\text {st }}$ century, after weapons and pharmacological drugs. Large companies will come in this field and scholars in universities may become content providers only (Katz 2012).

European universities must join the movement. Otherwise the space will be filled by initiatives coming from other places.

One thing is definitevely sure: building a $M O O C$ must not be done at university level. The aim of the project, its business model must be defined first. Otherwise MOOCs will remain sympathetic but isolated initiatives, not able to achieve their goals. iTypa, for instance, without a large publicity, has already been able to reach 1,400 people all around the worlds, mostly in French speaking countries of course. African students have been very enthusiastic. This shows that Europe has its place, with its variety of cultures, and that people around the world are waiting for our proposals.

The project is ambitious:

- Human resources are needed to prepare the content: lesson development, formatting, scripting, etc.

- $\quad$ Resources are required to implement the solution: platform, server, website, etc

- It is mandatory to rapidly offer a large range of courses. Each contributor can only bring a few items, considering the work and the requirement to mobilize staff. Many universities must assemble together and define common goals.

There are two alternatives:

- National consortiums: the UK has started with FutureLearn. In France the Open Educational Repositories, Universités Numériques Thématiques (UNT http://www.universitesnumeriques.fr/) are working on a project. Other countries are certainly working also on such national projects.

- Consortiums at a European scale, where a number of universities will provide content in their own language, is a strong alternative. Such consortiums would be a good representation of the European cultural diversity. A European organization such as the Trans-European 
Research and Education Networking Association (TERENA http://www.terena.org) could be the technical operator for the servers and the platform. The European University Information System Organization (EUNIS http://www.eunis.org) could act as an intermediary body, a link between the technicians on the one hand and the course designers (academic staff) on the other.

The main challenge remains to solicit the academic partners. This is a strategic point and universities must take initiatives very quickly through their own channels (direct links, European Universities organization such as the European University Association (EUA http://www.eua.be), the League of European Research Universities (LERU http://www.leru.org), the European Association of Distance Education Universities (EADTU http://www.eadtu.eu). The European Community is also a natural partner and leader.

$M O O C$ is a great opportunity for European universities to reach the public who will never come on our campuses and, as we say in French: "the meal is passing once, do not hesitate".

\section{REFERENCES}

Educause (2012) General references about MOOC, http: / / www.educause.edu/library/search?keys=MOOC\&filters=

Educause (2012) What Campus Leaders Needs to Know about MOOCs, http://www.educause.edu/library/resources/what-campus-leaders-need-know-aboutmoocs

Epelboin Y. \& Desnos JF (2002) Does the American Approach to Information Technology apply to Europe? The cultural paradigm?, Educause Congress 2002 http://www.educause.edu/library/resources/does-american-approach-informationtechnology-apply-europe-cultural-paradigm

Fischer K. (2011) Crisis of confidence threatens Colleges, Chronicle of Higher Education May 15, 2011 http://chronicle.com/article/A-Crisis-of-Confidence/127530/

Hill, P. (2012) Online Educational Delivery Models: A Descriptive View, Educause Review November/December 2012, http://www.educause.edu/ero/article/online-educationaldelivery-models-descriptive-view

Innovatice (2012) Le cours magistral a-t-il un avenir ? (A future for the course from the chair?), colloqium on Innovation in Teaching (in French) http://video.upmc.fr/differe.php?collec=S_C_innovatice2012

iTyPa (2012) a c-MOOC experience in France, http://itypa.mooc.fr

Katz R. (2012) Edu@2025 Video, http:/ /www.youtube.com/watch?v=07KnT4Fg9Go

Khan, S. (2006) Khan Academy http://www.khanacademy.org

Lewin T. (2013) Public Universities to Offer Free Online Classes for Credit, New York Times January 23, http://www.nytimes.com/2013/01/23/education/public-universities-to-offer-freeonline-classes-for-credit.html?hpw\&_r=0

Mc Carthy K. \& Abrams N. (2012) America's Student Debt Crisis, Huffington Post May 14, http://www.huffingtonpost.com/kyle-mccarthy/student-debt-crisis_b_1777116.html

Mc Ghee P. (2012) Why online courses can never totally replace the campus experience, The Guardian, 19-11-2012, http://www.guardian.co.uk/education/2012/nov/19/open-onlinecourses-higher-education?CMP=email

OCW (2002) MIT OpenCourseware Initiative http://ocw.mit.edu/index.htm

Tracey, R. (2013) The moot points of MOOC in e-Learning Provocateur, http://ryan2point0.wordpress.com/

WGU (1995) Western Governors University http://www.wgu.edu/ 


\section{AUTHORS' BIOGRAPHIES}

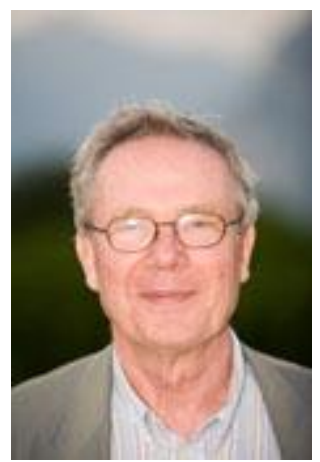

Yves Epelboin is Professor of Physics at UPMC. He got is Doctorate of Sciences at UPMC in 1974. He has been working in the US, at IBM Research in the 80's, for $2 \frac{1}{2}$ years, where he engaged in massive use of computing for his research in the interaction of X-Rays with highly ordered materials such as Silicon. Back to France he created the first intensive computing center at UPMC and took responsibilities at national levels in University Information Systems. He is one of the EUNIS founders and its second President. Nowadays he is, at UPMC, the Director of the General Service for Information Technology for Teaching and Learning. 